\title{
PENGEMBANGAN MEDIA PEMBELAJARAN FISIKA BERBASIS FREZI PADA MATERI USAHA DAN ENERGI
}

\section{DEVELOPMENT OF PHYSICS LEARNING MEDIA BASED ON FREZI IN WORK AND ENERGY MATERIALS}

\author{
Fira Amanta ${ }^{1}$, Indra Gunawan ${ }^{2}$, Wan Jamaluddin ${ }^{3}$ \\ ${ }^{1,2}$ Prodi Pendidikan Fisika Fakultas Tarbiyah dan Keguruan Universitas Islam Negeri Raden Intan \\ Lampung \\ ${ }^{3}$ Prodi Manajemen Pendidikan Islam Fakultas Tarbiyah dan Keguruan Universitas Islam Negeri Raden \\ Intan Lampung
}

E-mail: firaamanta20@gmail.com

Diterima: 30 April 2019. Disetujui: 28 Mei 2019. Dipublikasikan: 31 Juli 2019

\begin{abstract}
This study aims to produce products through the development of Frezi-based physics learning media on business materials and energy at the VIII grade of junior high school level, knowing the feasibility of the media according to the validators and knowing the responses of students to the media. This research is $R \& D$ research. The types of data produced are quantitative and qualitative data which are analyzed by the guideline of assessment criteria to determine product feasibility. This study resulted in Frezi-based learning media products on business materials and energy at the junior high school class VIII the final product produced had shown to be very feasible with an average score of material expert assessment $81 \%$, media experts with an average score of $80 \%$. learning media obtained in small group trials are very good with an average score of $87 \%$. In the field trials obtained very good criteria with an average score of $88.33 \%$. This frezi-based physics learning media has been qualified to use as a learning media.
\end{abstract}

Keywords: learning media, frezi, work and energy.

Abstrak: Penelitian ini bertujuan untuk menghasilkan produk melalui pengembangan media pembelajaran fisika berbasis Frezi pada materi usaha dan energi tingkat SMP kelasVIII, mengetahui kelayakan media menurut para validator dan mengetahui respon peserta didik terhadap media. Penelitian ini merupakan penelitian $R \& D$. Jenis data yang dihasilkan adalah data kuantitatif dan kualitatif yang dianalisis dengan pedoman kriteria penilain untuk menentukan kelayakan produk. Penelitian ini menghasilkan produk media pembelajaran berbasis Frezi pada materi usaha dan energi tingkat SMP kelas VIII produk akhir yang dihasilkan telah menunjukan sangat layak dengan skor rata-rata dari penilaian ahli materi 81\%, ahli media dengan skor rata-rata $80 \%$ Respon peserta didik terhadap media pembelajaran yang diperoleh pada uji coba kelompok kecil yaitu sangat baik dengan skor rata-rata $87 \%$. Pada uji coba lapangan diperoleh kriteria sangat baik dengan skor rata-rata sebesar 88,33\%. Media pembelajaran fisika berbasis Frezi ini sudah terkualifikasi digunakan sebagai media pembelajaran.

(C) 2019 Unit Riset dan Publikasi Ilmiah FTK UIN Raden Intan Lampung

Kata Kunci: media pembelajaran, frezi, usaha dan energi

\section{PENDAHULUAN}

Fisika adalah cabang sains paling dasar, karena berhubungan dengan perilaku dan struktur benda (Giancoli, 2001).Fisika merupakan ilmu eksperimental. fisikawan mengamati fenomena alam dan berusaha menemukan pola dan prinsip yang menghubungkan fenomena-fenomena ini. Pola ini disebut teori fisika atau ketika mereka sudah benar-benar terbukti dan digunakan luas disebut hukum atau prinsip fisika.Fisika merupakan salah satu mata pelajaran dalam rumpun sains yang sangat erat kaitannya dengan kehidupan sehari-hari manusia (Saregar, 2016). 
Pembelajaran fisika bisa dimulai dari diri pendidik dengan memberikan pengajaran yang lebih mudah dipahami dan dimengerti oleh peserta didik, pemilihan media pembelajaran yang interaktif akan membantu proses penyampaian informasi atau materi dengan baik dan mudah dimengerti oleh peserta didik.(Diani, 2016).Namun kenyataannya, dalam proses pembelajaran masih ditemukan pembelajaran yang bersifat teacher centered, text book oriented, dan pendidik menggunakan media belajar seadanya atau malah tidak menggunakan media. Pendidik menyampaikan materi sesuai dengan apa yang ada pada buku ajar yang digunakan saja, tanpa memberikan kesempatan atau memfasilitasi peserta didik untuk bereksplorasi lebih jauh. Keadaan seperti ini peserta didik menjadi kurang aktif, minat belajar kurang, peserta didik tidak bisa belajar secara mandiri tanpa adanya pendidik.(Yuberti, 2014)

Perkembangan teknologi yang semakin pesat dari waktu ke waktu menuntut perubahanpada berbagaibidang kehidupan, salah satunya diantaranya adalah bidang pendidikan.Perubahan pada bidang pendidikan diperlukan untuk dapat meningkatkan kualitas suatu pendidikan.(Melida, Masril, \& Hufri, 2014)Dengansemakinberkembangnyailm upengetahuandanteknologi,

mempermudahsetiap orang untuk mengakses informasi apapun yang ingin didapatkan termasuk dibidang pendidikan dalam mempermudah proses pembelajaran.

Teknologi dalam pendidikan bukan hanya sebatas menggunakan computer saja, namun bagaimana menggunakan teknologi untuk berkolaborasi dan berkomunikasi melakukan penelitian, sertamenyelesaikan proses pembelajaran yang semakinkompleks danberkembang secara dinamis. (Azhar, 2011). Dengan semakin berkembangnya teknologi dunia pendidikan kita harus selalu peka terhadap perkembangan tersebut dan berpikirmaju untuk memanfaatkan dan mengembangkannya kembali dalam menjadikan teknologi tersebut sebagai alat bantu media pembelajaran dalam proses pembelajaran. Dalam proses belajar mengajar kehadiran media mempunyai arti penting, karena dalam kegiatan tersebut ketidakjelasan bahan yang disampaikan dapat dibantu dengan menghadirkan media sebagai penunjang. Media dapat mewakili apa yang kurang mampu pendidik ucapkan melalui katakata atau kalimat tertentu. Bahkan keabstrakan bahan dapat dikonkritkan dengan kehadiran media.Dengan demikian peserta didik lebih mudah mencerna bahan dari pada tanpa bantuan media.(Syaiful Bahri Djamarah, 2014)Agar peserta didik memiliki minat belajar maka proses pembelajaran yang dilaksanakan oleh pendidik harus berjalandengan baik dan efektif.Salah satu upaya yang dapat dilakukan agar proses pembelajaran dapat menarik perhatian dan dapat membangkitkan minat belajar peserta didik yaitu menggunakan media pembelajaran yang tepat dengan materi yang akan diberikan. Hal ini dikembangkan melalui pembelajaran IPA, karena IPA memiliki struktur dan keterkaitan yang kuat dan jelas antar konsepnya.

Pemanfaatan media dalam pembelajaran dapat membangkitkan keinginan dan minat baru, meningkatkan motivasi dan rangsangan kegiatan pembelajaran dan bahkan berpengaruh secara psikologis pada peserta didik.(Diani, Yuberti, \& Syafitri, 2016)Jadi dalam pemanfaatan media pembelajaran sangat membantu dalam proses pembelajaran dan sangat berpengaruh bagi peserta didik dalam minat belajar.Minat sangat besar pengaruhnya terhadap hasil belajar, karena apabila bahan pelajaran yang dipelajari tidak sesuai dengan minat, peserta didik tidak akan belajar dengan 
baik sebab tidak menarik baginya. Peserta didik akan malas belajar dan tidak akan mendapatkan kepuasan dari pelajaran itu.

Hadirnya teknologi pada saat ini membawa segala urusan kehidupan manusia menjadi lebih baik dan menjadi lebih mudah. (Yuberti, 2014). Salah satu media yang bisa menjadi alternatif adalah frezi.Freziadalah salah satu perangkat lunak pembuatan slide presentasi secara online.Berbeda dengan powerpoint, frezimemberikan ruang yang lebih bebas untuk menuangkan kreasi dalam pembuatan slide presentasi.Frezimemiliki tampilan seperti mind map, sehingga lebih memudahkan peserta didik untuk memahami materi yang disampaikan.(Saputri, Irafahmi, \& Sumadi, 2016)keunggulan dari media pembelajaran ialah memiliki tema yang bervariasi serta dilengkapi dengan zoomable canvaspada sistem pengoprasiannya, sehingga membuat tampilan frezimenjadi lebih menarik. Zoomable camvas memungkinkan pengguna tidak perlu berpindah dari satu slide ke slide lain. Cukup hanya dengan satu kanvas besar yang bisa disisipi gambar video, teks dan lain-lain. Hal ini akan memudahkan peserta didik untuk memahami informasi yang sedang disampaikan.(Putri Zakiyatul, Diah, \& Fathiah, 2014).

\section{LANDASAN TEORI}

\section{Pembelajaran IPA}

Belajar menurut pandangan B.F Skinnr (195) dalam buku metodologi pembelajran ipa merupakan adaptasi atau penyesuaian tingkah laku yang berlangsung secara progresif. Belajar dipahami sebagai suatu prilaku jadi belajar merupakan perubahan peluang terjadinya respon. (Asih Widi W, 2014). Belajar juga merupakan usaha yang dilakukan manusia untuk mencapai tujuan yang telah ditentukan. Proses belajar dpat terjadi secara sengaja maupun tidak sengaja, yang kesemuanya itu mempunyai keuntungan dan mudah diamati.

Fisika adalah ilmu pengetahuan yang paling mendasar, karena berhubungan dengan prilaku dan struktur benda (Giancoli, 2001). Fisika adalah ilmu eksperimental. Fisika merupakan materi, energi, dan fenomena atau gejala alam, baik yang bersifat makroskopis (berukuran besar) mikroskopis (berukuran kecil). Dalam belajar fisika, yang pertama dituntut adalah kemampuan untuk pemahaman konsep, prinsip maupun hukum-hukum, kemudian diharapakan peserta didik mampu menyusun kembali dalam bahasanya sendiri sesuai dengan tingkat kematangan dan perkembangan intelektualnya.

\section{Frezi}

Frezi adalah sebuah perangkat lunak untuk presentasi berbasis internet. Selain untuk presentasi, frezi juga dapat digunakan sebagai alat untuk mengeksplorasi dan berbagi ide diatas kanvas virtual, frezimenjadi unggul karena program ini menggunakan zooming user interface (ZUI), yang memungkinkan pengguna freziuntuk memperbesar dan memperkecil tampilan media presentasi.(Putri Zakiyatul et al., 2014). Program frezimerupakan salah satu aplikasi terbaru yang memiliki tampilan presh, unik, menarik dan memiliki kecanggihan dalammemperbesar dan memperkecil tampilan serta dapat memadukan antara video, gambar maupun animasi.Frezi menawarkan sebuah layar kosong yang disebut kanvas.Pencipta presentasi dapat menambahkan item konten seperti kotak teksBerbagai ukuran, gambar, atau klip video.(Resor-Whicker \& Tucker, 2015).Softwarefrezi ini dapat digunakan sebagai media pembelajaran inovatif.Pembelajaran dilakukan dengan menggunakan laptop atau komputer yang telah ter-install softwarefrezi, dikombinasikan dengan LCD dan perangkat audio.(Asih Widi W,

219 Indonesian Journal of Science and Mathematics Education ( I J S M E ) 
2014)Arah inovasi ini adalah agar pembelajaran dikelas menjadi lebih menarik dan efektif serta menambah minat belajar peserta didik.

\section{METODE PENELITIAN}

Penelitian yang digunakan oleh peneliti ini adalah model prosedural Borg and Gall, yaitu model deskriptif yang menggambarkan langkah-langkah prosedur atau alur yang harus dilakukan untuk menghasilkan produk baru atau mengembangkan produk yang telah ada sehingga semakin meningkat efektifitas dan efisiensi suatu sistem.(sugiyono, 2017).Operasionalisasi penelitian ini, digunakan prosedur yangdiformulasi dari Borg and Gall, yaitu: Tahapan Pendahuluan: (1) studi pendahuluan; Tahapan Pengembangan: perencanaan, (3)produksi tahap awal, (4) uji cobaawal, (5) revisi produk utama, (6) uji coba lapangan utama, (7) revisi produk operasional, (8) uji lapangan operasional, (9) revisi produk final;Tahapan Implementasi: (10)menetapkan Model yang akandigunakan.(Yuberti, 2014).

Hal ini diperkuat oleh sugiyono bahwa metode penelitian dan pengembanngan atau dalam bahasa inggrisnya Resech and Devlopment adalah metode penelitian yang digunakan untuk menghasilkan suatu produk tertentu dan menguji keefektifan produk tersebut.Dalam penelitian dan pengembangan model Borg and Gall yang telah dimodifikasi oleh Sugiyono dibutuhkan sepuluh langkah prosedur untuk menghasilkan produk akhir yang siap untuk diterapkan dalam lembaga pendidikan. Tetapi, peneliti membatasi penelitian pengembangan dari sepuluh langkah menjadi tujuh langkah dikarenakan keterbatasan waktu dan juga peneliti hanya ingin melihat produk layak atau tidak digunakan sebagai suplemen atau tambahan pembelajaran IPA dikelas, serta melihat respon kemenarikan dari peserta didik jadi tidak sampai menyebarluaskan.

Jenis data yang digunakan dalam penelitian pengembangan ini terdiri dari data kuantitatif dan kualitatif. Data kuantitatif berupa skor penilaian setiap poin kriteria penilaian pada angket kualitas media pembelajaran berbasis frezi pada materi usaha dan energi tingkat SMP kelas VIII.Yang diisi oleh ahli media, ahli materi, pendidik serta peserta didik sebagai pengguna. Penilaian untuk setiap poin kriteria diubah menjadi skor dengan skala Likert, yaitu 5=Sangat Baik, 4=Baik, 3=Cukup Baik, 2=Kurang, $1=$ Sangat Kurang.Data kualitatif yaitu data yang berbentuk deskripsi kalimat dan berupa kritik dan saran dari ahli media dan ahli materi terhadap pengembangan media pembelajaran fisika berbasis frezipada materi usaha dan energi tingkat SMP kelas VIII.

Setelah ditemukan masalah pada tahap sebelumnya, selanjutnya perlu dilakukan pengumpulan data dengan melakukan pengkajian terhadap perangkat pembuatan media sehingga diperoleh data sebagai berikut: 1) Pengkajian materi Pada tahap ini ditentukan materi yang akan disampaikan pada peserta didik, perangkat media dan penggunaannya. Materi yang dipilih dalam penelitian ini adalah usaha dan energi tingkat SMP kelas VIII. 2) Perangkat pembuatan media Setelah ditetapkan materi yang akan dikemas dalam media pembelajaran, tahap selanjutya adalah pengkajian perangkat pembuatan media. Alat dan bahan yang digunakan dalam mengembangkan produk meliputi: 1) software(a) Perangkat lunak untuk sistem operasi:window 7 home ultime(b)Frezi dekstop 2) Hardware(a) Prosesor intel inside (b) RAM 1 GB(c) Monitor 256 colour dengan resolusi 1366 × 768 (d) Hardisk minimal 120 GB (e) Compack disk (CD)(f) Sistem operasi windows 7 home ultimate2) Buku IPA kelas VIII. 
Setelah mengumpulkan informasi, selanjutnya membuat produk awal media pembelajaran, selanjutnya peneliti mendesain produk awal yang akan dikembangkan yaitu berupa pengembangan media pembelajaran fisika berbasis frezipada materi usaha dan energi tingkat SMP kelas VIII.

Adapun langkah-langkah yang dilakukan dalam pembuatan media pembelajaran berbasis frezi ini adalah:

a. Menganalisis materi yang akandibahas

b. Menyusun media frezi sesuai dengan standar kompetensi

c. Menambahkan gambar, animasi, simulasi, dan video pada media frezi

d. Membuat evaluasi soal yang dibuat berdasarkan indikator yang telah disusun. Berfungsi sebagai sarana bagi peserta didik untuk menguji penguasaan materi yang telah dipelajari.

Setelah itu melakukan validasi desain adapun langkah-langkah peneliti lakukan, yaitu sebagai berikut:

1) Menentukan indikator peneliti yang digunakan untuk menilai produk yang telah dibuat.

2) Menyusun instrumen penilaian produk berdasarkan indikator penilaian yang telah ditentukan.

3) Melaksanakan penilaian produk yang dilakukan oleh ahli desain bahan ajar atau media pembelajaran.

4) Melakukan analisis terhadap hasil penilaian produk untuk menghasilkan produk yang lebih menarik.

5) Merumuskan rekomendasi perbaikan berdarkan hasil penilaian, dan

6) Mengkonsultasikan hasil rekomendasi perbaikan yanng telah diperbaiki kepada pembimbing.

Setelah validasi produk selesai dilakukan, maka langkah selanjutnya adalah memperbaiki desain yang dianggap masih kurang oleh validator desain.

Setelah melakukan validasi desain dan melakukan perbaikan produk maka selanjutnya melakukan tahap uji coba produk.Pada tahap uji coba produk maka terlebih dahulu peneliti melakukan simulasi penggunaan media pembelajaran berbasis frezipada materi usaha dan energi tingkat SMP kelas VIII.Setelah disimulasikan, maka penelitian dilanjutkan dengan uji coba pada kelompok yang terbatas.Kelompok tersebut terdiri dari 10 peserta didik dari tiga sekolah SMP Negeri 28 Bandar Lampung, SMP Amal Bakti Jatiagung dan SMP Al-Huda Jatiagung Lampung Selatan.Uji coba ini dimaksudkan untuk mendapatkan informasi apakah media yang dikembangkan dalam menyampaikan pembelajaran lebih efektif, bermanfaat dan mengetahui respon peserta didik terhadap media tersebut pada materi usaha dan energi dibandingkan media pembelajaran yang digunakan sebelumnya. Adapun langkah yang dilakukan adalah sebagai berikut:

1. Mengumpulkan peserta didik

2. Memberikan arahan penggunaan media pembelajaran fisika berbasis frezi

3. Melaksanakan kegiatan pembelajaran menggunakan media pembelajaran berbasis frezi sebagai media pembelajaran fisika untuk meningkat minat belajar peserta didik pada materi usaha dan energi tingkat SMP

4. Menyebar angket respon peserta didik

5. Menghitug respon peserta didik

Dari hasil uji coba produk, apabila tanggapan peserta didik mengatakan bahwa produk ini baik dan menarik, maka dapat dikatakan bahwa media pembelajaran berbasis frezipada pokok bahasan usaha dan energi ini telah selesai dikembangkan sehingga menghasilkan produk akhir. Namun apabila produk belum sempurna maka hasil dari uji coba ini dijadikan bahan perbaikan dan penyempurnaan media frezipada pokok bahasan usaha dan energi yang dibuat, sehingga dapat menghasilkan produk akhir yang siap digunakan disekolah.

221 Indonesian Journal of Science and Mathematics Education ( I J S M E ) 


\section{HASIL DAN PEMBAHASAN}

Penelitian dan pengembangan ini dilaksanakan di tiga sekolah yaitu SMP Negeri 28 Bandar Lampung, SMP Amal Bakti Jatiagung Kabupaten Lampung Selatan, dan SMP Al-Huda Jatiagung Kabupaten Lampung Selatan. Langkah pengembangan yang dilaksanakan oleh penelitian adalah modelBorg and Gall yang telah dimodifikasi oleh Sugiono dari tahap 1 sampai tahap 7. Berikut ini disajikan data dari setiap tahapan penelitian:

\section{Potensi dan Masalah}

Potensi dalam penelitian pengembangan ini yaitu mengembangkan media pembelajaran fisika berbasis frezipada materi usaha dan energi tingkat SMP kelas VIII. Pada landasan teori ditemukan teori-teori yang mendukung tentang kelayakan dan fungsi media frezi sebagai media pembelajaran. Berdasarkan kajian pustaka, frezidapat menggeser pradigma pembelajaran yang semula berpusat pada pendidik menjadi berpusat pada peserta didik dan pendidik hanya sebagai fasilitator sehingga peserta didik menjadi aktif belajar, tidak lagi mengandalkan pendidik sebagai narasumber tunggal. Kelebihan frezi adalah dapat menampung keberagaman gaya belajar, karena frezidiprogram agar dapat menampilkan media visual, audio, maupun animasi. Program aplikasi frezijuga merupakan media yang unik karena di dalamnya terdapat bentuk presentasi yang sangat berbeda dengan presentasi umumnya.

\section{Mengumpulkan Data}

Pra penelitian atau observasi lapangan dilakukan untuk mengetahui kebutuhan pendidik dan peserta didik mengenai media pembelajaran frezi.Observasi lapangan dilakukan dengan menyebar kuisioner dan wawancara tertulis dengan pengisian angket kepada pendidik. Kriteria pertanyaan observasi adalah mengenai keterampilan yang dimiliki oleh pendidik dalam menggunakan dan mengembangkan media pembelajaran, kurangnya minat dalam proses pembelajaran dan tanggapan peserta didik dalam menggunakan media pembelajaran frezi.

Hasil dari pra penelitian atau observasi lapangan yang didapatkan yaitu, perlunya pemanfaatan media pembelajaran fisika berbasis frezi pada materi usaha dan energi tingkat SMP kelas VIII dan perlunya dilakukan pengembangan media frezisebagai media pembelajaran.

\section{Hasil Desain Produk}

Berdasarkan data hasil pra penelitian atau obsevasi lapangan, maka spesifikasi produk yang akan dikembangkan adalah media pembelajaran freziyang dapat membantu pendidik dan peserta didik dalam proses pembelajaran. Berikut adalah perencanaan pengembangan media pembelajaran fisika berbasis frezisebagai media pembelajaran IPA yang dikembangkan:

a. Melakukan analisis materi yang akan dibahas.

b. Menyusun media frezisesuai dengan standar kompetensi, kompetensi dasar, indikator dan tujuan pembelajaran.

c. Karena kekurangan media frezisulit untuk memasukan simbol matematika maka pembuatan media frezi membutuhkan bantuan software lain seperti microsoft word dan paint, dimana microsoft word digunakan untuk menulis persamaan yang kita gunakan kemudian kita tekan pada cybord ctrl-prt sc sysrq kemudian kita paste ke dalam paint.

d. Membuat evaluasi soal yang dibuat berdasarkan indikator yang telah disusun. Berfungsi sebagai sarana bagi peserta didik untuk menguji pengusaan materi yang telah dipelajari. 


\section{Kelayakan Media}

Setelah produk telah berhasil dikembangkan langkah selanjutnya adalah melakukan uji keyakan model dengan cara validasi produk. Validasi desain atau produk dilakukan setelah pembuatan produk awal.Validasi dilakukan dengan 2 macam yaitu validasi ahli materi dan validasi ahli media.Sebelum melakukan validasi desain atau produk, terlebih dahulu melakukan validasi instrumen penelitian oleh dosen ahli.Lembar validasi

\section{- Persentase;}

Kesesuaian Maturi Persentase; Dengan SK \& KDKeakuratan Media;

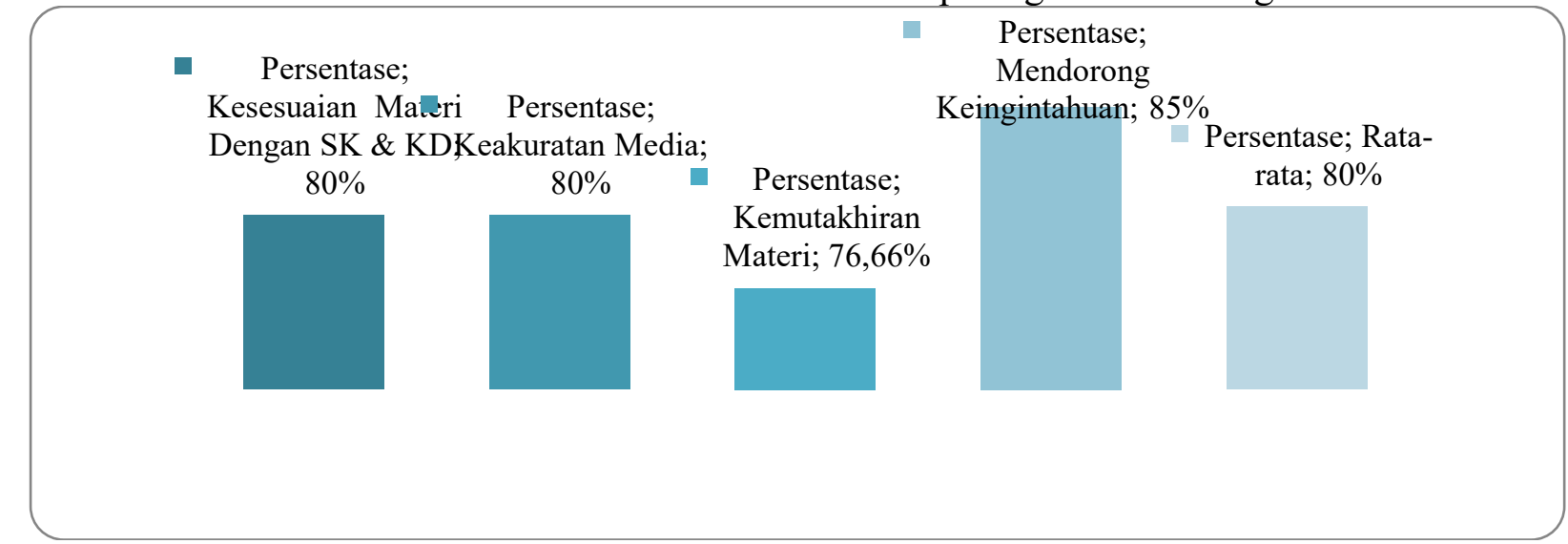

diberikan kepada 2 orang ahli materi dan 2 orang ahli media sebagai validator.

a. Validasi Ahli Materi

Validasi ahli materi dilakukan dengan mengisi lembar angket penilaian pada masing-masing aspek terdapat beberapa pernyataan dari 4 aspek terdapat beberapa pernyataan 13 seluruhnya diisi oleh 2 orang ahli materi yaitu Bapak Antomi Saregar, M.Pd, M.Si, Ibu Happy Komikesari, M.Si. Hasil validasi ahli materi dapat dilihat pada gambar 1 sebagai berikut:

Gambar 1. Presentase Penilaian Ahli Materi Tahap 1

Berdasarkan hasil grafik presentase $80 \%$, kemutakhiran materi 76,66, validasi ahli materi menunjukan aspek mendorong keingintahuan $85 \%$ dan ratakesesuain materi dengan SK \& KD rata diperoleh nilai $80 \%$ merupakan diperoleh nilai $80 \%$, keakuratan media kriteria "Layak"

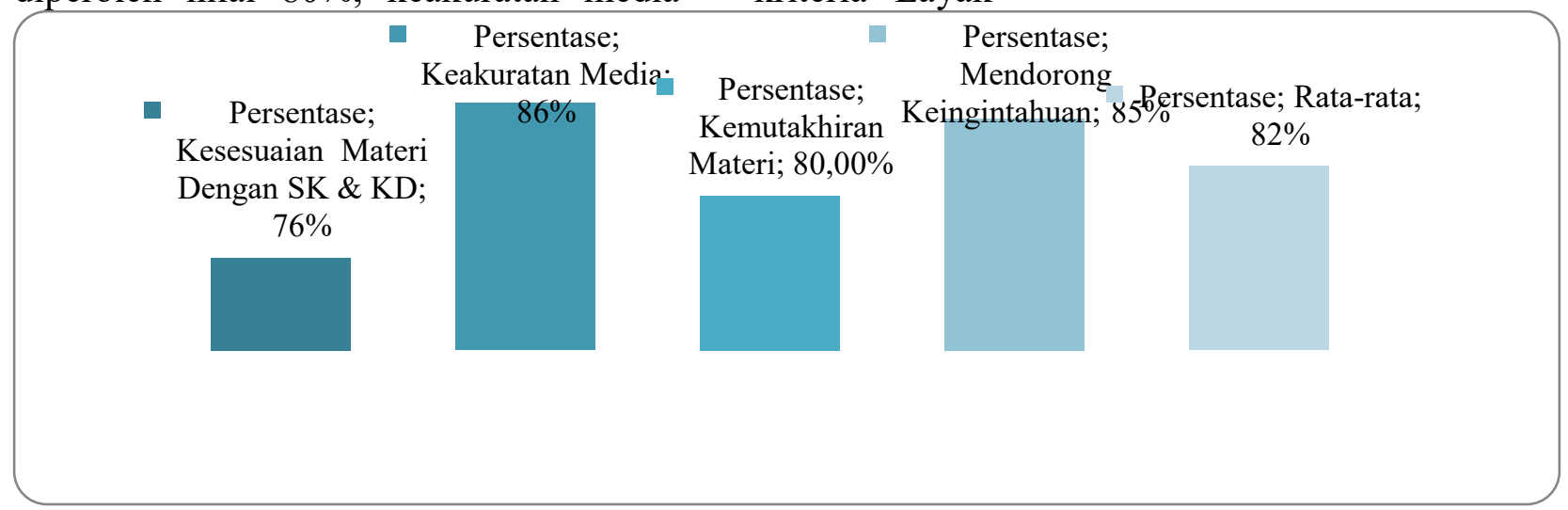

Gambar 2. Presentase Penilaian Ahli Materi Tahap 2

Berdasarkan hasil grafik presentase validasi ahli materi menunjukan aspek kesesuain materi dengan SK \& KD diperoleh nilai $76 \%$, keakuratan media $86 \%$, kemutakhiran materi $80 \%$, mendorong keingintahuan $85 \%$ dan ratarata diperoleh nilai $82 \%$ merupakan kriteria "Sangat Layak". b. Validasi Ahli Media

Validasi ahli media dilakukan dengan mengisi lembar angket penilaian pada masing-masing terdapat 2 aspek yang terdiri dari 9 pernyataan seluruhnya diisi oleh 2 orang ahli media yaitu Widya Wati,M.Pd dan Bapak Irwandani, M.Pd. Data validasi oleh ahli media: 


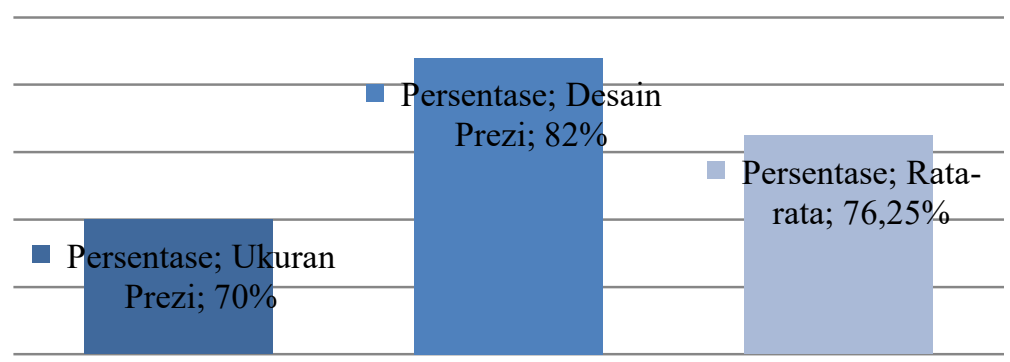

- Ukuran Prezi

- Desain Prezi

Rata-rata

Gambar 3. Presentase Penilaian Ahli Media Tahap 1

Berdasarkan hasil grafik presentase validasi ahli media pada aspek ukuran frezi menunjukan presentase $70 \%$, pada aspek desain frezi menunjukan presentase $82 \%$ dan rata-rata presentase senilai $76 \%$ merupakan kriteria "Layak".

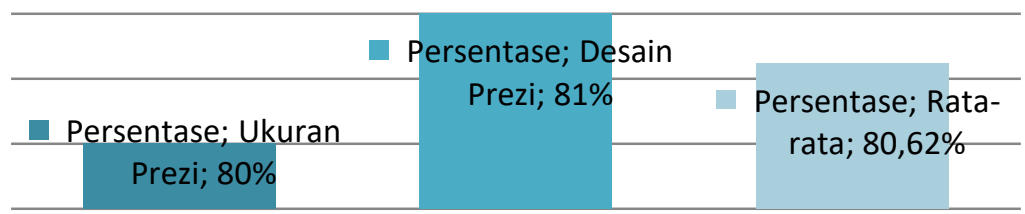

- Ukuran Prezi

Desain Prezi

Rata-rata

Gambar 4. Presentase Penilaian Ahli Media Tahap 2

Berdasarkan hasil grafik presentase validasi ahli media pada aspek ukuran frezi menunjukan presentase $80 \%$, pada aspek desain frezi menunjukan presentase $81 \%$ dan rata-rata presentase senilai 80,62\% merupakan kriteria "Layak".

\section{Hasil Revisi Desain}

Setelah validasi produk selesai dilakukan oleh validator materi dan ahli media maka didapat saran dari para validator.Kemudian saran yang diberikan dijadikan masukan untuk merevisi desain produk awal.

\section{Uji Coba Produk}

Uji coba media pembelajaran fisika berbasis frezipada materi usaha dan energi tingkat SMP kelas VIII yang telah direvisi ini dilakukan di 3 sekolah.Uji coba meliputi uji coba kelompok kecil dan uji coba lapangan. Uji coba dilakukan pada saat proses pembelajaran berlangsung. Setelah melakukan pembelajaran dengan media pembelajaran fisika berbasis frezi peserta didik diminta untuk mengisi angket tanggapan atau respon.

Berdasarkan uji coba kelompok kecil yang dilaksanakan di tiga sekolah yaitu SMP Negeri 28 Bandar Lampung, SMP Amal Bakti Jatiagung dan Al-Huda Jatiagung Lampug Selatan dapat disatukan, berikut hasil grafik uji coba uji coba penggunaan media pembelajaran: 


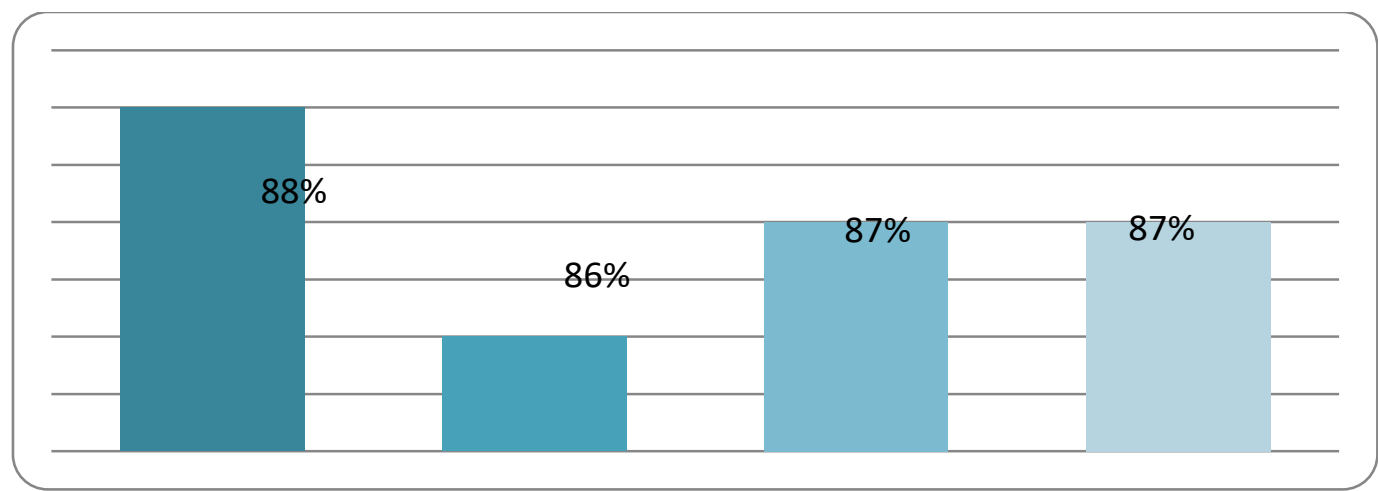

Gambar 5. Presentase Uji Kelompok Kecil

Dari hasil grafik diperoleh rata-rata skor respon uji coba kelompok kecil di tiga sekolah. Pada aspek materi diperoleh nilai $88 \%$ merupakan kriteria sangat baik, penialian aspek bahasa diperoleh nilai $86 \%$ merupakan kriteria sangat baik dan aspek kemenarikan diperoleh nilai $87 \%$ merupakan kriteria sangat baik. Dari ketiga aspek memperoleh hasil rata-rata skor senilai $87 \%$ dengan kriteria sangat baik.

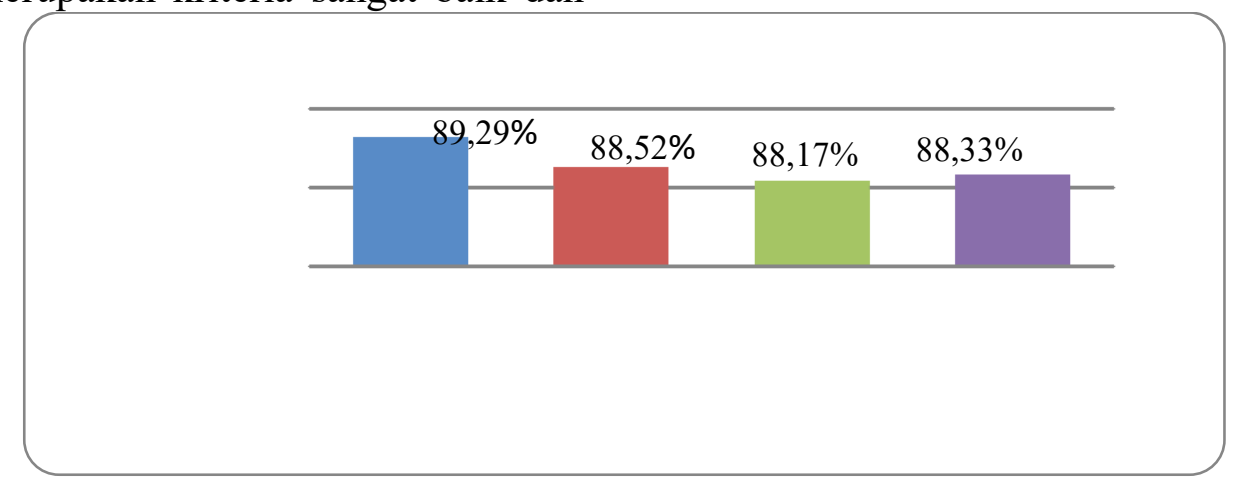

Gambar 6. Presentase Uji Coba Lapangan

Dari grafik diatas diperoleh hasi ratarata skor tanggapan uji coba lapangan di tiga sekolah.Penilaian aspek materi mendapat nilai 89,29\% dengan kriteria sangat baik. Penilaian aspek bahasa mendapat nilai $88,52 \%$ dengan kriteria sangat baik. Penilaian aspek kemenarikan mendapat nilai $88,17 \%$ dengan kriteria sangat baik. Dari ketiga aspek penilaian didapat hasil rata-rata skor sebesar $88,33 \%$ dengan kriteria sangat baik.

\section{KESIMPULAN}

Berdasarkan hasil analisis data dan pengolahan data maka disimpulkan bahwa Telah dikembangkan media pembelajaran berbasis frezipada materi usaha dan energi tingkat SMP kelas VIII. Media pembelajaran ini dibuat dengan menggunakan program frezi next windows dekstop dengan bantuan software lain seperti paint untuk mengedit gambar yang telah di screenshoot dari laptop, Microsoft Word untuk mengetik materi yang akan dijadikan pokok bahasan dalam media frezi. Kemudian setelah semua bahan siap di satukan pada slide frezi.

Pengembangan media pembelajaran fisika berbasis frezi pada materi usaha dan energi tingkat SMP kelas VIII sangat baik digunakan dalam pembelajaran. Kriteria produk berdasarkan ahli materi $82 \%$ dengan penilaian kriteria "Sangat Layak" dan kriteria penilaian produk berdasarkan penialaian ahli media memperoleh nilai presentase $81 \%$ dengan penilaian kriteria "Sangat Layak".

Respon peserta didik pada uji coba kelompok kecil terhadap media pembelajaran fisika berbasis frezi memperoleh nilai rata-rata $87 \%$ dengan kriteria "Sangat baik", sedangkan respon peserta didik pada uji lapangan terhadap 
media pembelajaran fisika berbasis frezimemperoleh nilai rata-rata $88,33 \%$ dengan kriteria "Sangat baik". Dengan demikian media pembelajaran fisika berbasis frezi pada materi usaha dan energi tingkat SMP kelas VIII ini layak digunakan sebagai media pembelajaran.

\section{DAFTAR PUSTAKA}

Asih Widi W, E. S. (2014). Metodologi Pembelajara IPA. Jakarta: PT Bumi Aksara.

Azhar, A. (2011). Media Pembelajaran. Media Pembelajaran, (1)

Diani, R. (2016). Pengaruh Pendekatan Saintifik Berbantukan LKS terhadap Hasil Belajar Fisika Peserta Didik Kelas XI SMA Perintis 1 Bandar Lampung. Jurnal Ilmiah Pendidikan Fisika Al-Biruni, 5(1)

Diani, R., Yuberti, Y., \& Syafitri, S. (2016). Uji Effect Size Model Pembelajaran Scramble dengan Media Video Terhadap Hasil Belajar Fisika Peserta Didik Kelas X MAN 1 Pesisir Barat. Jurnal Ilmiah Pendidikan Fisika Al-Biruni, 5(2)

Giancoli, D. C. (2001). Fisika Edisi Ke 5 Jilid 2. Jakarta: Erlangga.

Melida, D., Masril, \& Hufri. (2014). Pengaruh Media Frezi The Zooming Presentations Terhadap Hasil Belajar Fisika Siswa Kelas XI SMA N 12 Padang. Pillar Of Physics Education, 4(November), 113.

Putri Zakiyatul, Z., Diah, M., \& Fathiah, A. (2014). Penggunaan Media Pembelajaran Zooming Presentation Untuk Meningkatkan Hasil Belajar Siswa Kelas X Pada Konsep Suhu Dan Kalor. EDUSAINS, VI(2).

Resor-Whicker, J., \& Tucker, K. R. (2015). Using Frezi to Structure Online Videos for Information Literacy Instruction: A Case Study. Internet Reference Services Quarterly, 20(3-4)

Saputri, I. J., Irafahmi, D. T., \& Sumadi, S. (2016). Media Presentasi Frezi
Pada Mata Pelajaran Akuntansi Untuk Meningkatkan Motivasi Belajar Siswa. Journal of Accounting and Business Education, 2(4).

Saregar, A. (2016). Pembelajaran Pengantar Fisika Kuantum dengan Memanfaatkan Media Phet Simulation dan LKM Melalui Pendekatan Saintifik: Dampak pada Minat dan Penguasaan Konsep Mahasiswa. Jurnal Ilmiah Pendidikan Fisika Al-Biruni, 5(1). sugiyono. (2017). Metode Penelitian Kuantitatif, Kualitatif, dan $R \& D$. Bandung: Alfabeta.

Syaiful Bahri Djamarah, A. Z. (2014). Strategi Belajar Mengajar. Jakarta: PT Rineka Cipta.

Yuberti. (2014). "Penelitian dan Pengembangan" yang Belum Diminati dan Perspektifnya. Jurnal Ilmiah Pendidikan Fisika Al-Biruni, 3(2) 